the library's role is not much different from that for the first two years of the teachers' college; it is chiefly to furnish required readings in as adequate a number of copies as possible. For the terminal vocational program, the library does little more than furnish collateral reading for the occasional student who wants to go beyond his text or who wants background for his laboratory work. Only in a few special cases have we done more. For work in cooperative retailing, the reference department has serviced pamphlet materials gathered by the instructor, keeping them in the vertical file and in pamphlet boxes and handling them much like other pamphlets. Guidance material, particularly that issued by the Science Research Associates, has been treated in the same way, in cooperation with the department of counseling.
The library tries to help the faculty bring home to all students, terminal and other, the nature of the war, the United Nations idea, and the importance of unity behind the war effort within our own country. This has been done for the most part by purchasing increasing numbers of books along these lines and making available the periodicals which deal particularly with the war and postwar problems. This reading program has not developed to our satisfaction yet and is a challenge to the faculty and to the library. Perhaps students get a better understanding of the spirit animating the United Nations from participation in defense activities of various kinds than they do from reading about the war and the peace. We hope the library is at least a factor in understanding and unity and, therefore, in bringing victory and a lasting peace.

\title{
The Junior College Library and Terminal Education
}

Mr. Johnson is librarian and dean of instruction. Stephens College, and Miss Johns is librarian and research associate, Institute for Consumer Education Library, Stephens College.

$\mathrm{T}$ HE ROLE of the junior college library in terminal education is identical with its role in any other aspect of the educational program. In other words, the function of the library (in terminal education, in preparatory education, in professional education) is to cooperate with teachers and students in developing and carrying out the most effective methods of using library materials as an aid to attaining course objectives and-even more important-the objectives of individual students. More specifically, as the writers see the problem, the library must: 
I. Supply appropriate materials when and where they are needed for the effective attainment of instructional objectives.

2. Develop in students and teachers attitudes and habits of work which lead to the continuous use of tools of learning, such as the library can provide, as aids to meeting problems and attaining goals in everyday living.

3. Teach students how to find and obtain tools of learning so that they will continue the use of such materials in day-by-day living after leaving school.

Since under this concept the library is an integral part of the instructional program, its objectives must be the same as those of the college of which it is a part. Terminal education in terms of goals may be vocational (preparation for making a living) or general (preparation for effective living in areas common to all). At Stephens College terminal education is conceived to include both general education and vocational education.

Illustrative of this is the case of Mary Jones, who is training to be a secretary. During her two years at Stephens Mary studies shorthand, typewriting, office practice, office machines, and secretarial accounting. But these courses take less than half of her time; the major part of her time is spent in such general education activities as humanities, social problems, psychology, communications, general biology, consumers' problems, and design for living. She also participates in extraclass experiences such as student government, speech clinic, grooming clinic, and clubs which relate to her interests. These courses and activities are designed to aid her in living more effectively.

As an integral part of the instructional program at Stephens College the library works closely with the teaching program in all departments. Members of the li- brary staff attend divisional and departmental meetings, visit classes, teach classes, serve on faculty committees, and, all in all, function as members of the instructional staff.

Since in previous descriptions ${ }^{1}$ of the Stephens College library program illustrations of practice have largely been drawn from general education courses (communications, literature, social problems, etc.), this presentation will draw upon an illustration from a newly developed vocational area-aviation.

\section{Aviation Instruction}

Aviation instruction was begun with the offering of a course in introduction to aviation in the fall of 1941. Planned to aid students in making vocational choices and to give a general background of training needed for positions in aviation, this course was from the beginning offered with the cooperation of several airlines. Experience with the course and study of the vocational needs and opportunities in aviation has now led to the establishment, in cooperation with twelve major airlines, of a two-year course of study providing general education and vocational training necessary for employment in a variety of aviation positions.

As has been suggested, the role of the library in such new terminal courses as aviation is the same as its role in longerestablished courses. Selection of materials appropriate to the objectives of the courses thus becomes a first consideration. In this field, as in any other field, materials must be accurate, up to date, and teachable. Airline consultants aided in developing and checking bibliographies for technical accuracy and application to job require-

${ }^{1}$ Johnson, B. Lamar. Vitalizing a College Library. American Library Association, 1939. 
ments. Books and magazines considered were examined by teachers and librarians for teachability and readability.

Books purchased were first placed in the general library on reserve. Later a classroom library was set up. This soon proved impractical because the rapidly increasing enrolment in the field and the expanded number of related courses offered made the effective administration of the materials extremely difficult. Accordingly, aviation materials have for the most part been returned to the general library. Temporary classroom collections are, however, established as needed for selected units of instruction.

Our present organization now appears to meet adequately the instructional needs in aviation. Since, however, flexibility is an essential of functional library administration, the library staff is alert to the possibilities of developing new methods of making materials available when and where they are needed. Changes in circulation routines and location of materials will accordingly be made as required. Streamlining of ordering and cataloging routines to maintain a steady flow of ac- cessions is particularly helpful in meeting the changing needs of new fields of instruction.

The development of attitudes, habits, and skills in the effective use of tools of learning is an important function of each course in the curriculum. The attainment of these goals demands much more than the selection of appropriate materials and the location of such materials where they can be used most effectively. The methods for attaining these ends represent a significant instructional problem upon which teachers and librarians must work together in all fields.

\section{Summary}

I. The function of the library in terminal education is identical with its function in every other aspect of the educational program.

2. The selection of materials for some of the newer vocational courses requires the cooperation of practitioners in vocations as well as of teachers and librarians.

3. Flexibility of administration is a significant aid to meeting the instructional needs of an educational program.

\section{The Small Private School for Men}

Mr. MacInnes is instructor in economics and accounting, Ricker Junior College, Houlton, Maine, and was formerly librarian, Conant Library, Nichols Junior College, Dudley, Massachusetts.

$\mathrm{D}$ URING MY INCUMBENCY as librarian of Nichols Junior College the library was completely reorganized with a view to making it fit more adequately the needs of the institution. The educational program carried on was entirely professional and largely terminal, although some students did transfer after graduation to four-year colleges for further work in business administration. The great majority of the students went directly into business after graduation-that was before the 